\title{
Financial Reforms and Industrial Sector Growth: Bound Testing Analysis for Pakistan
}

Shahida Wizarat, Qazi Muhammad Adnan Hye *

Abstract:

This study investigates the relationship between the financial liberalization index and industrial sector growth for Pakistan. Annual time series data from 1971 to 2007 is used and ARDL bounds testing techniques are applied. In the short run both the financial liberalization index and the real interest rate speed up industrial sector growth. However, in the long run the financial liberalization index and real interest rate slow down industrial sector growth. The error correction terms indicate that $41 \%$ disequilibrium in the short run is adjusted every year in the long run.

Keywords: Financial Liberalization, Industrial Sector Growth, ARDL Estimation Method

JEL: G32, L0, C8

DOI: $10.2478 / \mathrm{v} 10033-010-0017-0$

\section{Introduction}

In Pakistan the industrial sector contributed $26.7 \%$ to the GDP and employed almost $28 \%$ of the labor force (2007-08)'. The industrial sector includes mining \& quarrying, manufacturing, construction, electricity and gas. This sector has the requisite finance for development. In general, the financing requirements of industry fall into two types. The first is fixed capital such as the purchase of land, construction of buildings and the purchase of machinery and replacement of machinery. The second is finance required for the purchase of raw materials, payment of wages and other running expenses. However, a number of studies on the industrial sector have confirmed that banks play an important role in financial intermediation, capital formation and attracting foreign direct investment in the industrial sector [Goldberg, 2007 \& Thomas, 2007]. Pakistan has taken various measures for financial reforms in order to strengthen the financial sector and to enhance the industrialization process and capital formation in the economy. The aim of this paper is to evaluate the impact of financial policy reforms on industrial sector growth in
Pakistan by employing the auto regressive distributed lag model (ARDL). The remaining part of the paper is organized as follows: Section II discusses the relevant literature. Section III presents the model, data collection and the methodological framework. Section IV reports the empirical results, while section $V$ concludes the paper.

\section{Literature Review}

In the theoretical literature on financial liberalization and growth three types of views are available. First, Joseph Schumpeter (1911) argued that the service

\footnotetext{
* Shahida Wizarat

Economics Department, Institute of Business Management (loBM), Karachi, Pakistan.

E-mail: shahida.wizarat@iobm.edu.pk

Qazi Muhammad Adnan Hye

Institute of Business Management (IOBM)

E-mail: adnan.economist@yahoo.com
}

${ }^{1}$ See Pakistan Economic Survey 2007-08. 
provided by financial intermediaries encourages economic development through channeling society's funds to the most innovating entrepreneurs. Goldsmith (1969) defined the positive link between financial development and economic activity. Hicks (1969) stated that industrialization needs funds for long term capital investment. These funds are available through a developed financial system. That is why financial development played a critical role in industrialization in England. McKinnon and Shaw (1973) presented the concept of financial liberalization enhancing growth. Further, the New Growth theory of Romer, (1986); Barro, (1991); Japelli and Pagano, (1994) and Levine (1997) comprehensively explained that the presence of financial markets enabled securities-optimistic savers to hold such assets, making liquid funds available for long term investment. Industrialization could not occur without this liquidity transformation. According to this view, the financial system offered financial services that are crucial for economic growth. The second view states that finance is relatively less important for economic growth. Robinson (1952) argues that economic growth leads to financial development. Lewis (1955) observed that financial markets expand as a result of economic growth. Lucas (1988) stated that physical capital, human capital and technological change are the only factors influencing economic growth. According to this view the real sector increases the demand for various financial services which is met by the financial sector. This view proposes that financial development simply pursues economic growth. The third judgment departs yet further to argue that financial development could have a potential negative impact on growth. Van Wijnbergen (1982) and Buffie (1984) stated that financial developments can have no impact or indeed a negative impact on economic growth. As the formal financial system develops, funds move from the controlled market to the formal market. Due to the restraint (reserve requirement) in formal markets all the funds cannot advance. This reduces domestic credit supply, giving rise to a credit crunch, which can retard economic growth by lowering investment and slowing production. Stiglitz (1994) stated that certain forms of financial repression can have a positive effect, for example, improving the average quality of the pool of loan applicants by lowering the interest rate; increasing firm equity by lowering the price of capital and accelerating growth if credit is targeted towards profitable sectors such as exports or sectors with technological spillovers.
We now review some recent empirical literature on finance and growth. Levine et al. (2000) empirically found financial intermediation to have a positive impact on economic growth in a sample of 74 countries. La Porta et al. (2002) found that greater government ownership of banks resulted in lower per capita GDP growth, even when initial financial intermediation development had a positive and significant effect. They used data pertaining to 92 countries. Khan and Qayyum (2006) used an autoregressive distributed lag (ARDL) approach to cointegration in order to determine the long-run relationship between financial liberalization, trade openness and economic growth in the case of Pakistan. They found that trade and financial policy reforms play an important role in enhancing growth.

On the other hand some studies have found that financial liberalization impedes economic growth instead of expediting it. Demirgue-kunt et al. (2001) report that banking crises may be greater in a liberalized financial system because the banks and other intermediaries have more freedom to take risk and financial liberalization is a significant factor leading to banking sector fragility. Arphasil (2001) examined the East Asian crisis (1997-98) due to interest rates and capital account liberalization, because financial liberalization leads to a credit boom, mostly on account of short-term borrowing from abroad. Such a boom leads to an unstable foundation, ultimately creating financial fragility or crises. Wade (2001) claims that it is dangerous to liberalize capital accounts when banks have little experience of the international market and non-banking institutions also borrow abroad. It is doubly dangerous when the financial sector is based on bank borrowing rather than being equity financed and when the exchange rate is pegged. Singh et al. (2003) disagreed with the perception of donors/creditors that the fundamental causes of the Asian crisis lay in the microeconomic behavior of economic agents in these societies which was due to the Asian way of doing business. Tornell, Westermann and Martinez (2004) empirically proved that financial liberalization increased the incidence of financial crises. Mete (2007) stated that financial liberalization rendered the Turkish economy vulnerable to currency crises. Behrman et al. (2009) found that increase in financial liberalization is associated with bank crises and other domestic and external shocks, and that higher schooling inequality reduces the impetus for liberalization brought on by bank crises in Latin America. 


\section{Model, Data and Methodological Framework}

To check the impact of financial liberalization on industrial sector growth in Pakistan, we employ a CobbDouglas function, as specified in equation (1) below:

$$
Y_{I}=A L_{I}^{\alpha} K_{I}^{\beta}---(1)
$$

Where $Y_{I}$ is industrial sector GDP, A is the residual containing the impact of the real interest rate and the composite financial liberalization index (FLI), etc. $L_{I}$ and $K_{I}$ are respectively labor and capital in the industrial sector, and $a \& \beta$ are the partial elasticities with respect to labor and capital respectively. Decomposing the residual and replacing partial elasticities by $\beta$ s we rewrite equation [2] as follows:

$$
\begin{aligned}
\operatorname{Ln}\left(Y_{I}\right)_{t}= & \beta_{0}+\beta_{1} F L I_{t}+\beta_{2} R I R_{t}+ \\
& +\beta_{3} \operatorname{Ln}\left(L_{I}\right)_{t}+\beta_{4} \operatorname{Ln}\left(K_{I}\right)_{t}+\mu_{1 t}---(2)
\end{aligned}
$$

Where $\operatorname{Ln}\left(Y_{I}\right)_{t}, \operatorname{Ln}\left(L_{I}\right)_{t}$ and $\operatorname{Ln}\left(K_{I}\right)_{t}$ are a natural logarithm of Gross Domestic Product, labor force and gross fixed capital formation in the industrial sector. RIR is the real interest rate, $F L I_{t}$ is the financial liberalization index and $\mu_{t}$ is the error term.

\subsection{Data Collection}

Data on $Y_{I}, L_{I}$ and $K_{I}$ are taken from various annual publications of the State Bank of Pakistan and various issues of the Pakistan Economic Survey. Gross Domestic Product and gross fixed capital formation in the industrial sector is measured in millions of rupees and industrial labor force is measured in millions of numbers. Real interest rate is nominal deposit rate minus the inflation rate. This study uses the financial liberalization index computed by Hye and Wizarat (2010), comprising eleven financial liberalization policy components to construct the time series on financial liberalization. The liberalization policy components are Islamization; interest rate deregulation; credit controls; stock market reforms; Prudential Regulations; privatization of financial institutions; removal of entry barriers; non-performing loans; external account liberalization; debt management reforms and open market operations. The financial liberalization index demonstrates that most of the liberalization measures were implemented by policy makers in Pakistan during the period of 1990-1996.

\subsection{Methodology Framework}

This paper uses Phillips and Perron's (1988) unit root test in order to determine the level of integration as it has small sample size properties (see details in Appendix-A). The Autoregressive Distributed Lag Model determines the long-run and short-run relationships between the variables, as proposed by Pesaran et al. (2001). This testing procedure is generally known as the bounds testing procedure or autoregressive distributed lag (ARDL) model. It has the following econometric advantages in comparison to other cointegration procedures. First, endogeneity problems and the inability to test hypotheses on the estimated coefficients in the long run associated with the Engle Granger method are avoided. Second, the long and short-run parameters of the model are estimated simultaneously. Third, all the variables are assumed to be endogenous. Fourth, the econometric methodology is relieved of the burden of pre-testing unit roots, and is applicable whether the underlying variables are $\mathrm{I}(0), \mathrm{I}(1)$, or fractionally integrated. The ARDL procedure involves investigating the existence of a long-run relationship in the form of an unrestricted error correction model as follows:

$$
\begin{aligned}
& \Delta L n\left(Y_{I}\right)_{t}=\beta_{0}+ \\
& +\beta_{1} \sum_{j=1}^{k} \Delta \operatorname{Ln}\left(Y_{I}\right)_{t-j}+ \\
& +\beta_{2} \sum_{j=o}^{k} \Delta F L I_{t-j}+ \\
& +\beta_{3} \sum_{j=0}^{k} \Delta R I R_{t-j}+ \\
& +\beta_{4} \sum_{j=0}^{k} \Delta \operatorname{Ln}\left(K_{I}\right)_{t-j}+ \\
& +\beta_{5} \sum_{j=0}^{k} \Delta L n\left(L_{I}\right)_{t-j}+ \\
& +\varpi_{1} \operatorname{Ln}\left(Y_{I}\right)_{t-1}+ \\
& +\varpi_{2} F L I_{t-1}+ \\
& +\varpi_{3} R I R_{t-1} \\
& +\varpi_{4} \operatorname{Ln}\left(K_{I}\right)_{t-1}+ \\
& +\varpi_{5} \operatorname{Ln}\left(L_{I}\right)_{t-1}+ \\
& +\mu_{1 t}----(3)
\end{aligned}
$$


The terms with summation signs in equation [3] represent error correction dynamics, while the second part (term with $\varpi s$ ) corresponds to the long-run relationship. F-tests are used for testing the existence of a long-run relationship. The null hypothesis defined by $\left\langle H_{0}: \varpi_{1}=\varpi_{2}=\varpi_{3}=\varpi_{4}=\varpi_{5}=0\right\rangle$ is tested against the alternative $\left\langle H_{0}: \varpi_{1} \neq \varpi_{2} \neq \varpi_{3} \neq \varpi_{4} \neq \varpi_{5} \neq 0\right\rangle$. However, the asymptotic distribution of this F-statistic is nonstandard, regardless of whether the variables are I(0) or I(1). The decision rule of a long-run relationship is as follows. If the computed F-statistic lies above the upper bound $[/(1)]$, then the null hypothesis can be rejected at a conventional level of significance, say $1 \%, 5 \%$ or $10 \%$, suggesting a co-integrating relationship among the variables. On the other hand, if the computed F-statistic lies below the lower bound $[/(0)]$, the null hypothesis cannot be rejected, indicating no co-integration in the relationship. The critical values of the lower and upper bounds are derived from the Turner (2006) response surface, according to the sample size. However, conclusive inference cannot be made when the test statistic falls within the lower and upper bounds. In this case, the time series properties must be known before any conclusion can be drawn (Pesaran et al., 2001). When a long-run relationship exists, the F-test indicates which variable should be normalized. If a long run relationship exists (co-integration) among the variables, the following long run model is estimated:

$$
\begin{aligned}
& \operatorname{Ln}\left(Y_{I}\right)_{t}=\beta_{0}+ \\
& +\sum_{j=1}^{k} \phi_{1 j} \operatorname{Ln}\left(Y_{I}\right)_{t-j}+ \\
& +\sum_{j=0}^{k} \beta_{1 j} F L I_{t-j}+ \\
& +\sum_{j=0}^{k} \beta_{2 i} R I R_{t-j}+ \\
& +\sum_{j=0}^{k} \beta_{3 i} \operatorname{Ln}\left(K_{I}\right)_{t-j}+ \\
& +\sum_{j=0}^{k} \beta_{4 i} \operatorname{Ln}\left(L_{I}\right)_{t=j}+ \\
& \quad+\eta_{t}-----(4)
\end{aligned}
$$

The orders of lags in the ARDL model are selected by minimizing the Schwarz Bayesian Criterion (SBC) and Akaike Information Criterion (AIC). The ARDL specification of the short-run dynamics can be derived by constructing an error correction model (ECM) of the following form:

$$
\begin{aligned}
\Delta \operatorname{Ln} & \left(Y_{I}\right)_{t}=\beta_{0}+ \\
& +\sum_{j=1}^{k} \phi_{1 j} \Delta \operatorname{Ln}\left(Y_{I}\right)_{t-j}+ \\
& +\sum_{j=0}^{k} \beta_{1 j} \Delta F L I_{t-j}+ \\
& +\sum_{j=0}^{k} \beta_{2 i} \Delta R I R_{t-j}+ \\
& +\sum_{j=0}^{k} \beta_{3 i} \Delta \operatorname{Ln}\left(K_{I}\right)_{t-j}+ \\
& +\sum_{j=0}^{k} \beta_{4 i} \Delta \operatorname{Ln}\left(L_{I}\right)_{t=j}+ \\
& +\lambda E C M_{t-1}+v_{t}----(5)
\end{aligned}
$$

Where, $E C M_{t-1}$ is the error correction term and $\lambda$ represents the speed of adjustment from short-run discrepancy to long-run equilibrium.

\section{Empirical Results}

Table-1 demonstrates the result of a unit root test: industrial sector $\operatorname{GDP}\left[\operatorname{Ln}\left(Y_{I}\right)\right]$, capital in the industrial

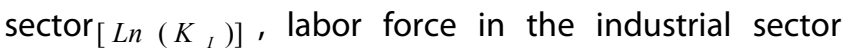
$\left[\operatorname{Ln}\left(L_{I}\right)\right]$, real interest rate (RIR) and financial liberalization index (FLI). The results indicate that the variables have unit root property in the level form but are stationary in the first difference form.

\begin{tabular}{|c|c|c|}
\hline \multirow{2}{*}{ Regressors } & \multicolumn{2}{|c|}{ Phillips Perron Unit Root Test } \\
\cline { 2 - 3 } & Level & $\mathbf{1}^{\text {st }}$ Difference \\
\hline $\operatorname{Ln}\left(Y_{I}\right)$ & -2.31 & $-6.05^{*}$ \\
\hline $\operatorname{Ln}\left(K_{I}\right)$ & -2.42 & $-4.12^{*}$ \\
\hline $\operatorname{Ln}\left(L_{I}\right)$ & -1.49 & $-7.12^{*}$ \\
\hline$R I R$ & -3.14 & $-5.08^{*}$ \\
\hline$F L I$ & 0.64 & $-2.37^{*}$ \\
\hline$*: 1 \%$ Level of significance \\
\hline
\end{tabular}

Table 1: Unit Root Test Results

The next step is to compute the F-Statistic. The reported [Table-2] F-Statistic [5.38] is greater than the upper bound critical value at the $5 \%$ level of significance, indicating a stable long-run relationship among the variables. 


\begin{tabular}{|c|c|c|}
\hline \multirow{3}{*}{ Critical Value } & F-Statistic & $\mathbf{5 . 3 8}$ \\
\cline { 2 - 3 } & $\begin{array}{c}\text { Lower Bound } \\
\boldsymbol{I ( 0 )}\end{array}$ & $\begin{array}{c}\text { Upper Bound } \\
\mathbf{I ( 1 )}\end{array}$ \\
\hline $\mathbf{1 \%}$ & 5.14 & 6.87 \\
\hline $\mathbf{5 \%}$ & 3.57 & 4.92 \\
\hline $\mathbf{1 0 \%}$ & 2.92 & 4.11 \\
\hline
\end{tabular}

Critical values derived from the Turner (2006) Response Surface Producer. Unrestricted intercept and no trend ( $k=4)$.

Table 2: Bounds Test for Long-Run Relationship

Through the ARDL bounds testing procedure, the estimated long-run and short-run coefficients are presented in Table-3 \& 4 below. Interestingly, the results show that the financial liberalization index and the real interest rate are negatively (statistically significant) associated with industrial growth, while labor and capital positively affect industrial growth in the long run.

\begin{tabular}{|c|c|c|}
\hline \multirow{2}{*}{ Regressors } & \multicolumn{2}{|c|}{$\begin{array}{c}\text { Dependent variable } \operatorname{Ln}\left(Y_{I}\right) \\
\text { Coefficients }\end{array}$} \\
\cline { 2 - 3 } & $\begin{array}{c}\boldsymbol{t} \text {-Ratio[P- } \\
\text { value] }\end{array}$ \\
\hline$F L I$ & -0.04 & $-1.87[0.07]$ \\
\hline$R I R$ & -0.006 & $-3.89[0.00]$ \\
\hline$L n\left(L_{I}\right)$ & 0.08 & $1.77[0.08]$ \\
\hline$L n\left(K_{I}\right)$ & 0.09 & $1.96[0.03]$ \\
\hline Constant & 3.55 & $3.01[0.00]$ \\
\hline R-Squared & \multicolumn{2}{|c|}{0.99} \\
\hline R-Bar-Squared & \multicolumn{2}{|c|}{0.99} \\
\hline F-stat[P-value] & \multicolumn{2}{|c|}{$2537.38[0.00]$} \\
\hline DW-statistic & \multicolumn{2}{|c|}{2.03} \\
\hline
\end{tabular}

Table-3: Long-Run Coefficients of the Industrial Growth Model

The coefficient on the financial liberalization index is 0.04 and the coefficient on the real interest rate is -0.006 , both confirming that a unit increase in the financial liberalization index and real interest rate causes industrial GDP to shrink by Rs. 1.04 million and Rs. 1.006 million respectively in the long run².

Table-4 represents the results of the ARDL based error correction model. The results indicate that financial liberalization and the real interest rate positively (at a four year lag) affect industrial growth in the short run.

\footnotetext{
${ }^{2}$ The antilog of the financial liberalization index and real interest rate coefficients are 1.04 and 1.006 respectively.
}

\begin{tabular}{|c|c|c|}
\hline \multirow{2}{*}{ Regressors } & \multicolumn{3}{|c|}{ Dependent variable $\Delta \operatorname{Ln}\left(Y_{I}\right)$} \\
\cline { 2 - 3 } & Coefficients & t-Ratio[P-value] \\
\hline$\Delta L n\left(Y_{I}(-1)\right)$ & -1.003 & $-25.47[0.00]$ \\
\hline$\Delta(F L I)$ & 0.24 & $17.97[0.00]$ \\
\hline$\Delta(R I R)$ & -0.003 & $-5.67[0.00]$ \\
\hline$\Delta(R I R(-1))$ & 0.0002 & $3.57[0.01]$ \\
\hline$\Delta L n\left(L_{I}\right)$ & -0.41 & $-7.62[0.00]$ \\
\hline$\Delta L n\left(K_{I}\right)$ & 0.61 & $16.92[0.00]$ \\
\hline$E C M(-1)$ & -0.41 & $-23.41[0.00]$ \\
\hline Constant & 2.14 & $10.84[0.00]$ \\
\hline R-Squared & \multicolumn{2}{|c|}{0.99} \\
\hline R-Bar-Squared & \multicolumn{2}{|c|}{$196.03[0.00]$} \\
\hline F-stat & 3.46 \\
\hline DW-statistic & \multicolumn{2}{|c|}{} \\
\hline
\end{tabular}

Table 4: Short Run Coefficients of Industrial Growth Model

Capital positively and labor negatively impacts industrial growth in the short run. The labor coefficient is negative because in the short run output cannot increase through an increase in labor force alone. The coefficient on the error correction term indicates that a $41 \%$ shortrun disequilibrium is adjusted every year.

\begin{tabular}{|l|c|c|}
\hline Test Statistics & LM Version & F Version \\
\hline A: Serial Correlation & - & $0.006[0.93]$ \\
\hline B: Functional Form & - & $0.13[0.71]$ \\
\hline C: Normality & $0.59[0.74]$ & - \\
\hline D: Heteroscedasticity & - & $0.83[0.36]$ \\
\hline
\end{tabular}

Table 5: Diagnostic Test Results

Table- 5 represents the diagnostic tests results. The test results confirm the validity of the long-run and short-run results. The stability of the selected ARDL model has also been evaluated using the cumulative sum (CUSUM) and the cumulative sum of squares (CUSUMSQ) of the recursive residual test for structural stability. The model appears stable and correctly specified because neither the CUSUM nor the CUSUMSQ test statistics exceed the bounds of the 5 percent level of significance (see Figures 1 \&2).

\section{Conclusion and Policy Recommendations}

The purpose of this study is to investigate the impact of financial reforms on industrial sector growth in the case of Pakistan by applying the semi-log function for the period 1971-2007. The empirical results indicate that the financial liberalization index and the real interest rate are negatively (statistically significant) associated with industrial growth, while labor and capital are positively 


\section{Plot of Cumulative Sum of Recursive Residuals}

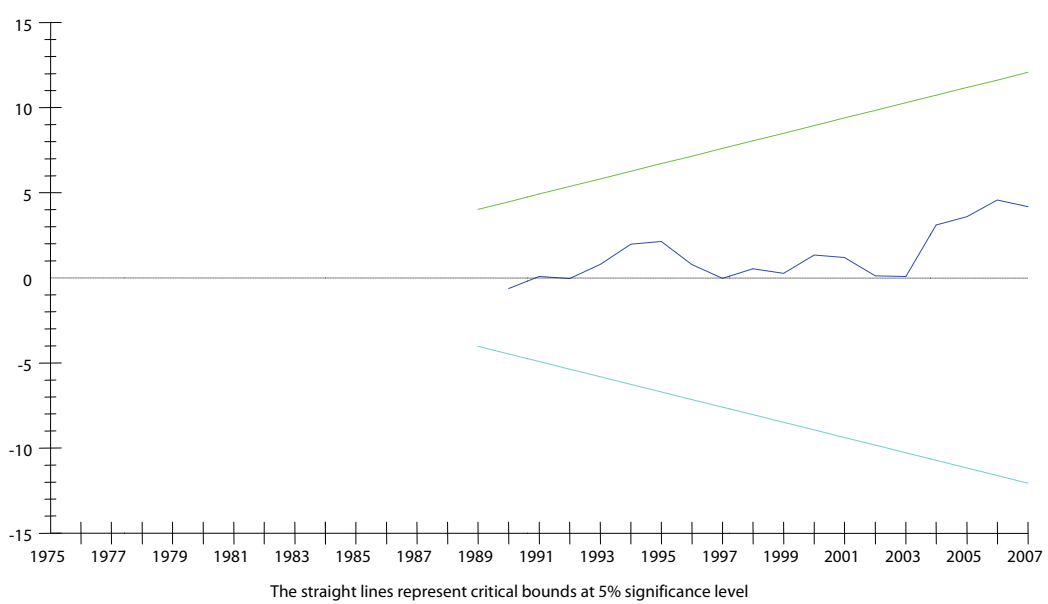

Figure 1: Cumulative Sum (CUSUM)

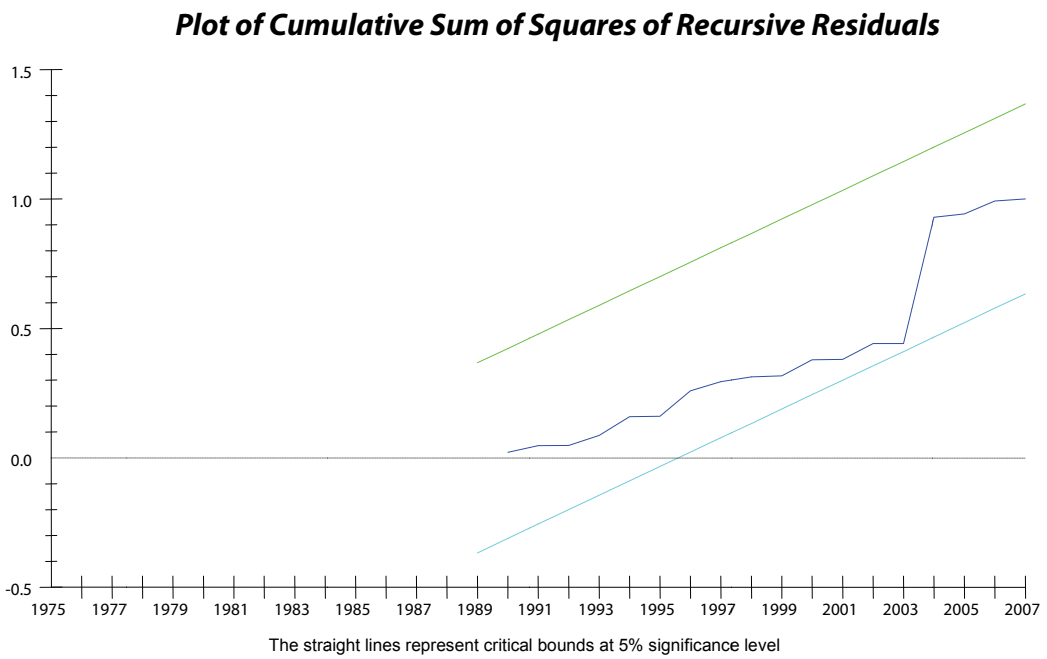

Figure 2: Cumulative Sum of Squares (CUSUMSQ)

associated with economic growth in accordance with the postulates of growth theory. In the short run the financial liberalization index and the real interest rate both show a robustly positive (statistically significant) relationship with economic growth. The empirical results indicate that financial liberalization impedes economic growth in the long run. The study recommends that Pakistan's policy makers revise financial liberalization to address its adverse impact on industrial sector growth.

\section{References}

Arphasil, P (2001). “Financial Liberalization and Financial Crisis: The Case of Thailand". In Masayoshi Tsurumi (Eds), Financial Big Bang in Asia. Aldershot, Ashgate Publishing Limited: pp.167-189.
Barro, R (1991). Economic Growth in a Cross Section of Countries. Quarterly Journal of Economics, 106: 407-443.

Behrman, J., Birdsall, N and Pettersson, G (2009). "Schooling Inequality, Crises, and Financial Liberalization in Latin America". Center for Global Development Working Paper No. 165.

Buffie, E.F. (1984). Financial Repression, the New Structuralists, and Stabilization Policy in Semi-industrialized Economies. Journal of Development Economics, 14: 305-322.

Demirgucs-Kunt, A and Enrica, D (2001). Financial Liberalization and Financial Fragility. In Gerald Caprio, Patrick Honohan and Joseph E. Stiglitz (Eds.), Financial Liberalization: How Far, How Fast? Cambridge, Cambridge University Press.

Engle, R.F and C.W.J Granger (1987). Cointegration and Error Correction: Representation, Estimation and Testing. Econometrica, 55(2): 251-276.

Goldberg, L.S (2007). Financial Sector FDI and Host Countries: New and old Lessons. FRBNY Economic Policy Review, 13(1): 1-17. 
Goldsmith, R.W (1969). Financial Structure and Development. New Haven, Yale University Press.

Gregory, A.W and Hansen, B.E (1996). Residual Based Tests for Cointegration in Models with Regime Shifts. Journal of Econometrics, 70 : 99-126.

Hicks, J (1969). A Theory of Economic Growth. Oxford Clarendon Press. Hye, Q.M.A and Wizarat, S (2010). Financial Liberalization Index for Pakistan.International Review of Applied Financial Issues and Economics, to be published in forthcoming issue.

Jappelli and Pagano, M (1994). Saving, Growth and Liquidity

Constraints. Quarterly Journal of Economics, 109: 83-109.

Johansen, S. (1991). Estimation and Hypothesis Testing of Cointegration Vectors in the Presence of Linear Trend. Econometrica, 59: 1551-1580.

Johansen, S. (1995). A Statistical Analysis of I (2) Variables. Econometric Theory, 11: 25-59.

Khan, M.A and Qayyum, A (2006). Trade Liberalization, Financial Sector Reforms and Growth. Available on http://mpra.ub.unimuenchen. de/2655/1/MPRA_paper_2655.pdf.

La Porta, R., Lopez-de-Silanes, F and Shleifer, A (2002). “Government Ownership of Banks". Journal of Finance, 57(1): 265-301.

Levine, R (1997). Financial Development and Economic Growth: Views and Agenda. Journal of Economic Literature, 35: 688-726.

Levine, R. and Beck, T (2000). "Financial Intermediation and Growth: Causality and Causes". Journal of Monetary Economics, 46(1): 31-77.

Lewis, W. A. (1955). The Theory of Economic Growth. London, George

Allen and Unwin Ltd.

Lucas, R.E. Jr. (1988). On the Mechanics of Economic Development. Journal of Monetary Economics, 22: 3-42.

McKinnon, R.I (1973). Money and Capital in Economic Development.

Washington DC, Brooking Institution.

Mete, F (2007). Financial Liberalization and currency Crises: The Case

of Turkey. Available at:

http://findarticles.com/p/articles/mi_qa5415/is_200704/ai_n21290633

Pesaran, M.H and Bahram, P (1997). Working With Microfit 4.0: Interactive Econometric Analysis. Oxford University Press.

Pesaran, M.H., Shin, Y and Smith, R.J (2001). Bound Testing Approaches to the Analysis of Level Relationships. Journal of Applied Econometrics, 16:289-326.

Phillips and Hansen (1990). Statistical Inference in Instrumental Variables Regression with I (1) Process. Review of Economic Studies, 57: 99-125.

Phillips, P.C and P. Perron. (1988). Testing for a Unit Root in a Time Series Regression. Biometrica, 75: 335-346.

Robinson, J (1952). The Generalization of the General Theory and Other Essays. London, the McMillan Press Ltd.

Romer, P.M (1986). Increasing Returns and Long-Run Growth. Journal of Political Economy, 94: 1002-1037.

Schumpeter, J.A (1911). The Theory of Economic Development: An Inquiry into Profits, Capital, Credit, Interest and the Business Cycle. Translated and Reprinted 1961, New York: Oxford University Press.

Schumpeter, J.A (1934). The Theory of Economic Development. Cambridge, MA, Harvard University Press.

Shaw, E.S (1973). Financial Deepening in Economic Development. New York, Oxford University Press.

Singh, A., Singh, A and Weisse, B (2003). "Corporate Governance, Competition, The New International Financial Architecture and Large Corporations in merging Markets". Publish in the Proceedings of the United Nations Conference On Trade and Development: 1-70

Stiglitz, J (1994). Economic Growth Revisited. Industrial and Corporate Change, 3(1): 65-110.
Thomas (2007). "Financial Sector Reforms and Manufacturing Growth in India: A Preliminary Analysis" Available on: http://www.igidr.ac.in/ money/mfc_10/Jayan\%20Jose\%20Thomas_sub mission_69.pdf.

Tornell, A., Westermann, F and Martinez, L (2004). The Positive Link between Financial Liberalization, Growth and Crises. National Bureau of Economic Research Working Paper No. 10293 (February).

Turner, P (2006). Response Surfaces for an F-test for Cointegration. Applied Economics Letters, 13: 479-482.

Van, W. S (1982). Stagflationary Effects of Monetary Stabilization Policies. Journal of Development Economics, 10: 133-169.

Wade, R (2001). From Miracle to Cronyism: Explaining the Great Asian Slump. In Chang, H., Palma, G and Whittaker, D.H (Eds), Financial Liberalization and the Asian Crisis. Hampshire and New York, Palgrave. 